\title{
PENGARUH PERSEPSI KUALITAS DAN CITRA MEREK TERHADAP LOYALITAS MEREK DALAM MEMBANGUN EKUITAS MEREK
}

\author{
Carissa Lorens Marchia Raharja ${ }^{1}$ \\ Ni Made Asti Aksari ${ }^{2}$ \\ ${ }^{1}$ Fakultas Ekonomi dan Bisnis Universitas Udayana (Unud), Bali, Indonesia \\ email: carissalorens@yahoo.com
}

\begin{abstract}
ABSTRAK
Tujuan dari penelitian ini adalah untuk menganalisis pengaruh persepsi kualitas dan citra merek terhadap loyalitas merek dalam membangun ekuitas merek sepatu Reebok. Populasi dalam penelitian ini adalah masyarakat yang sudah pernah menggunakan sepatu Reebok, dan sampel yang digunakan sebanyak 80 orang yang ditentukan dengan metode non probability sampling khususnya purposive sampling. Alat analisis yang digunakan dalam penelitian ini adalah PLS (Partial Least Square). Berdasarkan hasil analisis, persepsi kualitas berpengaruh secara positif dan signifikan terhadap loyalitas merek, citra merek berpengaruh secara positif dan signifikan terhadap loyalitas merek, dan loyalitas merek berpengaruh secara positif dan signifikan terhadap ekuitas merek. Untuk membangun ekuitas merek, Reebok sebaiknya fokus pada loyalitas pelanggan dengan memperhatikan persepsi kualitas dan citra merek yang ada di dalam benak pelanggannya.
\end{abstract}

Kata kunci : persepsi kualitas, citra merek, loyalitas merek, ekuitas merek

\begin{abstract}
The purpose of this study is to analyze the influence of perceived quality and brand image on brand loyalty towards Reebok shoes brand equity. The population of this study is people who have used Reebok shoes, while the study sample is 80 people determined using nonprobability sampling method specifically purposive sampling. The analytical tool used in this study is PLS (Partial Least Square). Based on the results of the analysis, perceived quality has a positive and significant effect on brand loyalty, brand image has a positive and significant effect on brand loyalty, and brand loyalty has a positive and significant effect on brand equity. To build brand equity, Reebok should focus on customer brand loyalty by paying attention to their customers' perceived quality and image of the brand.

Keywords: perceived quality, brand image, brand loyalty, brand equity
\end{abstract}




\section{PENDAHULUAN}

Olahraga adalah salah satu kegiatan yang perlu dilakukan oleh masyarakat Indonesia. Saat ini sebagian besar masyarakat sudah menjadikan olahraga sebagai gaya hidup dan dijadikan sebuah kebiasaan yang baik untuk kesehatan (Rafdi, 2015). Dengan begitu tercipta peluang yang dapat dimanfaatkan oleh perusahaan untuk menguasai pasar dalam memenuhi kebutuhan yang menyangkut kegiatan berolahraga.

Salah satu kebutuhan dalam berolahraga adalah sepatu olahraga. Di Indonesia, terdapat beberapa merek sepatu olahraga yang terdapat di pasaran. Merek-merek sepatu yang terdapat dipasaran mencoba untuk selalu berada dalam peringkat survei yang diadakan di Indonesia. Salah satu survei yang terdapat di Indonesia adalah Top Brand Award.

Hasil survey dari Top Brand Award dapat digunakan untuk menganalisis kinerja merek sehingga perusahaan dapat mengevaluasi dan menentukan strategi untuk menghasilkan peningkatan ekuitas merek. Untuk memperoleh informasi yang sangat dibutuhkan, Frontier Consulting Group mengembangkan konsep TOP BRAND, yaitu konsep penelitian yang didasarkan pada tiga konstruksi utama yaitu Mind Share, Market Share, dan Commitment Share.

Variabel pertama, mind share, menunjukkan kekuatan merek di dalam benak konsumen dari kategori produk masing-masing. Mind share berhubungan dengan kesadaran konsumen dan citra merek terhadap merek tertentu yang menjadi salah satu tujuan utama dari iklan dan promosi.

Variabel kedua yaitu market share menunjukkan kekuatan perusahaan di pasar (Kotler \& Amstrong, 2014). Variabel ketiga dalam Top Brand Award adalah commitment share menunjukkan kekuatan merek dalam mendorong konsumen untuk membeli merek itu di masa depan.

Berikut adalah merek sepatu olahraga yang terdapat di Indonesia yang disediakan oleh Top Brand Award Indonesia.

Tabel 1.

Top Brand Award Merek Sepatu Olahraga di Indonesia Tahun 2015-2017 (Dalam Persen)

\begin{tabular}{lllll}
\hline \multirow{2}{*}{ Merek Sepatu Olahraga } & \multicolumn{3}{c}{ Periode } & \multirow{2}{*}{ Kategori } \\
\cline { 2 - 4 } & Tahun & Tahun & Tahun & \\
\hline Adidas & 30,3 & 37,4 & 38,2 & TOP \\
Nike & 23,3 & 29,6 & 32,2 & TOP \\
Reebok & 6,3 & 3,7 & 3,3 & - \\
Converse & & 3,7 & 3,6 & - \\
Eagle & 3,0 & 3,7 & 3,3 & - \\
\hline
\end{tabular}

Sumber: Indonesia Top Brand, 2018

Salah satu variabel dalam pengukuran dari Top Brand Award adalah commitment share yang ditentukan dari loyalitas dari konsumen. Dalam Tabel 1, Reebok selalu mengalami penurunan sehingga dapat dilihat bahwa commitment share dari Reebok mengalami penurunan. 
Loyalitas merek merupakan simbol dari pemikiran konstruktif terhadap merek yang mengakibatkan pembelian merek secara terus-menerus (Aaker, 2013). Loyalitas merek adalah sebuah situasi dimana terdapat kemungkingan konsumen akan beralih ke merek lain ketika merek tersebut menjadi lebih baik dari harga maupun fiturnya (Aaker, 2013). Loyalitas merek juga merupakan bentuk sikap positif dari konsumen yang berupa komitmen terhadap sebuah merek lain. Loyalitas merek merupakan simbol pemikiran konstruktif, loyalitas merek akan berdampak baik bagi konsumen karena akan timbul rasa ingin membeli kembali terhadap suatu merek produk tertentu, walaupun dihadapkan pada banyak alternatif merek produk pesaing yang menawarkan karakteristik produk yang lebih unggul.

Ukuran ini mampu memberikan gambaran tentang mungkin tidaknya seorang pelanggan beralih ke merek produk lainnya, terutama jika terdapat perubahan pada produk tersebut, baik menyangkut harga ataupun atribut lain

Top Brand Award mengukur mind share dengan menentukan top of mind dari konsumen. Top of mind adalah merek pertama yang diingat dan disebutkan oleh konsumen. Dalam Tabel 1 penurunan ekuitas merek yang dialami Reebok disebabkan oleh mind share Reebok.

Menurut Kotler \& Keller (2012) semua perusahaan berusaha untuk membangun citra merek dengan asosiasi merek yang kuat, menguntungkan, dan unik. Konsumen dengan citra positif terhadap suatu merek lebih memungkinkan untuk melakukan pembelian

Menurut Aaker (2013) salah satu elemen dari ekuitas merek adalah persepsi kualitas dimana persepsi kualitas sendiri merupakan bagian penting dari studi dalam mengevaluasi ekuitas merek. Persepsi kualitas adalah persepsi konsumen terhadap keseluruhan kualitas atau keunggulan suatu produk dengan sesuatu yang diharapkan

Persepsi kualitas dapat didefinisikan sebagai keseluruhan persepsi pelanggan tentang kecemerlangan dan kualitas produk atau layanan yang diberikan. Persepsi kualitas merek merupakan sebuah evaluasi subjektif oleh konsumen terhadap merek yang dikonsumsi (Zeithaml et al., 2013:454)

Dalam website mengenai sepatu olahraga yaitu Runrepeat, terdapat beberapa keluhan terhadap sepatu Reebok. Keluhan yang banyak diutarakan oleh pengguna dari sepatu Reebok adalah daya tahannya.

Salah satu keluhan dari daya tahannya yaitu beberapa bagian lepas setelah pemakaian beberapa bulan. Selain itu, terdapat keluhan mengenai tali sepatu yang dirasa kurang panjang pada beberapa model sepatu Reebok. Keluhan pelanggan terhadap sepatu merek Reebok menunjukkan kualitas yang diberikan sepatu Reebok kurang baik.

Ekuitas merek menjadi topik yang penting dalam manajemen pemasaran. Ekuitas merek diciptakan oleh produk atau layanan untuk memberikan nilai secara langsung atau tidak langsung. Ekuitas merek adalah pengaruh diferensial positif yaitu jika pelanggan mengenal nama merek maka mereka akan merespons produk atau jasa. Berdasarkan teori tersebut, jika perusahaan mampu membuat merek yang kuat maka produk tersebut akan dikenal oleh konsumen dan dapat meningkatkan penjualan perusahaan. 
Menurut Janghyeon et al. (2011) ekuitas merek adalah serangkaian aset dan kewajiban yang terkait dengan sebuah merek, nama, dan simbol yang menambah atau nilai yang diberikan sebuah produk atau jasa kepada perusahaan dan atau pelanggan. Untuk menggabungkan persepsi kualitas, kesadaran merek, asosiasi merek, dan loyalitas merek dalam proses mengevaluasi tingkat ekuitas merek.

Dalam penelitian ini, peneliti menggunakan produk sepatu Reebok. Reebok International Ltd. adalah sebuah perusahaan perlengkapan dan alas kaki atletis. Produk sepatu Reebok bersaing dengan beberapa produk sepatu olahraga lainnya di Indonesia. Reebok menghasilkan dan mendistribusikan barang-barang fitness dan olahraga yakni sepatu, pakaian dan aksesoris kerja di luar ruangan, dan keperluan pelatihan.

Tabel 1. terdapat merek Adidas, Nike, Reebok, Converse, dan Eagle dalam kategori sepatu olahraga yang mampu bersaing di pasar saat ini. Reebok menjadi merek yang selalu mengalami penurunan setiap tahunnya. Pada tahun 2016 Reebok turun dari 6,3\% menjadi 3.7\%. Penurunan juga terjadi kembali di tahun 2017 yaitu menjadi $3,3 \%$.

Menurut Keller \& Lehmann (2006) pengukuran ekuitas merek dianggap sebagai topik penelitian yang relevan dengan peran strategis untuk dimainkan mengingat pentingnya memperoleh keunggulan kompetitif. Hasil pengujian Nofriyanti (2017) menunjukkan bahwa persepsi kualitas dan citra berpengaruh terhadap loyalitas merek.

Menurut Torres et al. (2015), loyalitas merek sangat mempengaruhi ekuitas merek. Dengan demikian, peneliti ingin menguji pengaruh persepsi kualitas dan citra merek terhadap loyalitas merek dalam membangun ekuitas merek untuk menyelesaikan masalah pada produk sepatu Reebok.

Berdasarkan latar belakang masalah yang telah diuraikan, maka penelitian ini bertujuan untuk menguji apakah persepsi kualitas berpengaruh terhadap loyalitas merek sepatu olahraga Reebok; apakah citra merek berpengaruh terhadap loyalitas merek sepatu olahraga Reebok dan apakah loyalitas merek berpengaruh terhadap ekuitas merek sepatu olahraga Reebok.

Hasil penelitian ini diharapkan menambah pengetahuan baik bagi manajemen Reebok mengenai pengukuran pengaruh persepsi kualitas dan citra merek terhadap loyalitas merek dalam membangun ekuitas merek. Selain itu juga diharapkan dapat menambah wawasan dan referensi kepustakaan mengenai ilmu pengetahuan di bidang pemasaran yaitu tentang pengaruh persepsi kualitas dan citra merek terhadap loyalitas merek dalam membangun ekuitas merek.

Merek merupakan aset yang paling berharga bagi perusahaan dan menjadi alasan penting bagi konsumen sebagai alat untuk memeriksa perbedaan produk termasuk keunikannya sehingga dapat memperkaya kepercayaan konsumen. (Chung et al., 2013; Emari et al., 2012; Huang \& Sarigollu, 2011). Branding telah diakui sebagai alat untuk membedakan satu produk dan layanan perusahaan di antara perusahaan pesaing lainnya.

Merek memungkinkan bagi perusahaan untuk berkompetisi dalam pasar produk dan jasa serta menunjukkan proposisi nilai dari strategi bisnis. Merek telah dianggap aset oleh sebuah perusahaan, merek dapat dikatan baik jika dapat memberikan nilai tambah serta manfaat bagi konsumen dan produsen. 
Ekuitas merek adalah nilai tambah yang diberikan pada produk dan jasa. Ekuitas merek adalah nilai dari suatu merek, yang meliputi elemen ekuitas merek yang tinggi serta aset lain (paten, merek dagang, dan hubungan saluran). Ekuitas merek mampu berperan sebagai identitas merek seperti logo, aset, merek dagang, dan slogan untuk dapat mengidentifikasi dan melihat bagaimana pengaruh produk terhadap konsumen (Alam et al., 2016).

Keller (2003) mendefinisikan ekuitas merek sebagai nilai yang secara langsung ataupun tidak langsung dimiliki oleh merek. Kotler (2015) menyatakan bahwa ekuitas merek berhubungan dengan brand assests dan liabilitas merek yang dapat menambah atau mengurangi nilai suatu produk terhadap suatu perusahaan.

Torres et al. (2015) menyatakan bahwa persepsi kualitas, kesadaran merek, dan loyalitas merek sangat mempengaruhi ekuitas merek secara keseluruhan. Dalam penelitian yang dilakukan oleh Sasmita \& Norazah (2014) mengungkapkan bahwa loyalitas merek berpengaruh signifikan terhadap ekuitas merek. Sasmita \& Norazah (2014) juga menyatakan bahwa citra merek memiliki dampak signifikan terhadap ekuitas merek.

Loyalitas merek adalah keterikatan yang dimiliki pelanggan terhadap merek (Kuscu \& Ozcam, 2014). Said (2014) mendefinisikan loyalitas merek sebagai kecenderungan respons emosional, evaluatif, dan / atau respons positif terhadap pilihan atau pilihan bermerek, berlabel atau dinilai oleh seseorang dalam kapasitasnya sebagai pengguna, pembuat pilihan, dan / atau agen pembelian.

Menurut Jing et al. (2014) loyalitas merek merupakan komitmen konsumen terhadap merek yang menjadikannya sebagai aset tak berwujud yang mencerminkan harga produk atau layanan perusahaan. Selain itu, loyalitas merek telah dinyatakan sebagai perasaan positif konsumen tentang merek yang sama, konsumen membeli merek lebih sering daripada yang lain serta membeli dan menggunakan merek yang sama untuk waktu yang lama (Kocoglu et al., 2015)

Pada penelitian sebelumnya Nofriyanti (2017) menyatakan loyalitas merek berpengaruh signifikan terhadap ekuitas merek. Torres et al. (2015) juga menyatakan bahwa persepsi kualitas adalah penggerak utama loyalitas merek. Fatema et al. (2013) menyatakan bahwa citra merek dan loyalitas merek memiliki pengaruh yang kuat terhadap ekuitas merek.

Persepsi kualitas adalah selisih penilaian pelanggan prospektif atas semua manfaat serta biaya dari sebuah penawaran. Perbedaan norma dalam keluarga, lingkungan, tujuan hidup, cita-cita dan lain sebagainya menyebabkan perbedaan pada persepsi kualitas (Setyawan, 2010). Konsumen akan mendapatkan keuntungan atas persepsi yang berasal dari konsumen itu sendiri (Putra \& Suryani, 2015).

Persepsi kualitas merek merupakan sebuah evaluasi subjektif yang berasal dari konsumen terhadap merek yang di konsumsi. Persepsi kualitas sebagai persepsi konsumen terhadap kualitas atau keunggulan suatu produk atau jasa sehubungan dengan tujuan yang diinginkannya, dibandingkan dengan alternatifalternatif lain

Menurut Sibagariang \& Nursanti (2010) citra merek adalah akumulasi asosiasi merek yang terbentuk dalam sudut pandang konsumen. Definisi citra merek menurut Zhang (2015) menunjukkan bahwa nama prestise akan sangat 
bergantung pada interpretasi dan pemahaman individu pada merek ditambah sikap atau penilaian baik atau buruk disertai oleh kecenderungan perilaku individu terhadap merek.

Citra merek (brand image) merupakan persepsi masyarakat terhadap perusahaan atau produknya. Citra merek merupakan deskripsi tentang asosiasi dan keyakinan konsumen tentang merek tertentu. Menurut Hasanah (2009) pengaruh brand image terhadap brand equity di awali dengan bagaimana brand image memberikan dampak strategis yang dominan pada peningkatan brand loyalty.

Penelitian mengenai persepsi kualitas terhadap loyalitas merek berhubungan positif dan signifikan (Vinh et al., 2017). Hasil pengujian juga menunjukkan bahwa persepsi kualitas berpengaruh signifikan terhadap loyalitas merek (Nofriyanti, 2017). Eliasari \& Sukaatmadja (2017) menyatakan bahwa persepsi kualitas berpengaruh positif signifikan terhadap loyalitas merek. Berdasarkan hal tersebut maka didapat hipotesis sebagai berikut.

$\mathrm{H}_{1}$ : Persepsi kualitas berpengaruh positif signifikan terhadap loyalitas merek

Pada penelitian sebelumnya, Kurniawan (2017) mengemukakan hasil positif dan siginifikan ditemukan dalam hubungan antara brand image terhadap brand loyalty. Nofriyanti (2017) menyatakan citra merek berpengaruh signifikan terhadap loyalitas merek.

Fatema et al. (2013) juga menyatakan citra merek dan loyalitas merek berpengaruh signifikan. Berdasarkan atas penelitian sebelumnya maka didapat hipotesis sebagai berikut.

$\mathrm{H}_{2}$ : Citra merek berpengaruh positif signifikan terhadap loyalitas merek

Efek pada ekuitas merek secara keseluruhan terhadap persepsi kualitas dan kesadaran merek dimediasi oleh loyalitas merek, dan loyalitas merek sangat mempengaruhi ekuitas merek secara keseluruhan (Torres et al., 2015) Loyalitas merek memiliki dampak positif pada ekuitas merek (Sasmita \& Norazah, 2014).

Selain itu, pengaruh loyalitas merek terhadap ekuitas merek secara signifikan (Kashif et al., 2015). Begitu pula dengan adanya pengaruh yang positif antara kesadaran merek terhadap terwujudnya loyalitas pelanggan. Berdasarkan atas penelitian sebelumnya maka didapat hipotesis sebagai berikut.

$\mathrm{H}_{3}$ : Loyalitas merek berpengaruh positif signifikan terhadap ekuitas merek

\section{METODE PENELITIAN}

Jenis penelitian ini menurut tingkat eksplanasinya merupakan penelitian asosiatif karena menjelaskan hubungan dua variabel atau lebih yaitu pengaruh persepsi kualitas dan citra merek terhadap loyalitas merek dalam membangun ekuitas merek.

Penelitian ini dilakukan di Kota Denpasar dan Kota Jakarta dengan menyasar pengguna sepatu Reebok. Pemilihan lokasi berdasarkan tingkat pendapatan upah minimum provinsi (UMP) tertinggi di Jawa-Bali. Provinsi DKI Jakarta dan Bali menempati UMP tertinggi diantara provinsi lainnya di Jawa-Bali (Hamdani, 2018)

Menurut Indriani (2015), tingkat pendapatan berpengaruh positif terhadap tingkat konsumsi. Hal ini berarti semakin tinggi UMP maka tingkat konsumsinya 
akan lebih tinggi. Kota Jakarta mewakili Pulau Jawa karena memiliki UMP tertinggi di Pulau Jawa dan Kota Denpasar mewakili Pulau Bali.

Objek dalam penelitian ini adalah pengaruh persepsi kualitas dan citra merek terhadap loyalitas merek dalam membangun ekuitas merek di Kota Denpasar dan Kota Jakarta. Subjek penelitian ini adalah konsumen yang pernah membeli dan menggunakan produk sepatu Reebok.

Populasi dalam penelitian ini adalah masyarakat yang sudah pernah membeli dan menggunakan produk sepatu Reebok. Dengan demikian, jumlah populasi yang digunakan dalam penelitian ini adalah infinite atau tidak terhingga, karena luasnya jangkauan penelitian.

Teknik penentuan sampel pada penelitian ini menggunakan non probability sampling dengan metode purposive sampling, yaitu sampel ditentukan dengan pertimbangan tertentu.

Kriteria sampel dalam penelitian ini sebagai berikut: 1) Pendidikan terakhir minimal SMA/SMK atau yang sederajat. 2) Responden yang sudah pernah menggunakan sepatu Reebok dalam 5 tahun terakhir. Pertimbangan ini digunakan agar responden dapat memberikan penilaiannya terhadap Reebok.

Jumlah indikator yang terdapat dalam penilitian ini adalah 16 dan dikalikan dengan 5 sehingga jumlah sampel yang digunakan di penelitian ini adalah 80 responden.

Data kualitatif dalam penelitian ini berupa pendapat dari responden terhadap pertanyaan dalam kuesioner mengenai pengaruh persepsi kualitas dan citra merek terhadap loyalitas merek dalam membangun ekuitas merek. Data kuantitatif dalam penelitian ini berupa data mengenai persentase sepatu olahraga yang ada di Indonesia tahun 2015-2017 berdasarkan peringkat Top Brand Indonesia.

Sumber data primer dalam penelitian ini merupakan tanggapan responden dalam kuesioner mengenai variabel-variabel dalam penelitian. Sumber sekunder dalam penelitian ini merupakan institusi atau pihak lain yang telah mempublikasikan data yang dikutip terkait dengan topik penelitian ini, seperti website, jurnal, dan lain sebagainya.

Metode pengumpulan data dalam penelitian ini yaitu dengan melakukan penyebaran kuisioner yang dilakukan sendiri oleh peneliti. Penyebaran kuisioner dilakukan dengan cara online.

Penyebaran kuisioner secara online dilakukan dengan mengumpulkan data yang disebarkan melalui Google Form. Penelitian ini menggunakan kuisioner dalam pengumpulan data. Sebelum dilakukan penyebaran kuisioner akan diuji dengan uji validitas dan realibilitas.

Statistik deskriptif adalah statistik yang digunakan untuk menganalisis data dengan cara mendeskripsikan data yang telah terkumpul untuk membuat kesimpulan. Statistik deskriptif berupa rata-rata skor jawaban dari kuesioner. Rata-rata skor jawaban responden pada kuesioner dikelompokkan kedalam 5 kelas interval dengan formula sebagai berikut

Dalam penelitian ini untuk menguji hipotesis dan membuat kesimpulan menggunakan Partial Least Squares (PLS). PLS merupakan metode analisis yang diperkenalkan oleh Herman Worl yang sering disebut dengan soft modeling. 
Dengan menggunakan PLS, pemodelan persamaan structural dapat dilakukan dengan ukuran sampel yang relatif kecil dan tidak membutuhkan asumsi normal multivariate.

\section{HASIL DAN PEMBAHASAN}

Karakteristik responden penelitian merupakan profil dari 80 responden yang telah berpartisipasi dalam pengisian kuesioner penelitian ini. Profil responden memaparkan jenis kelamin, usia, pendidikan terakhir dan pekerjaan.

Secara lebih jelas, karakteristik responden disajikan pada Tabel 2 berikut.

Tabel 2.

Karakteristik Responden

\begin{tabular}{ccccc}
\hline No. & Karakteristik & Klasifikasi & Jumlah Orang & Presentase(\%) \\
\hline 1. & Jenis kelamin & Laki - laki & 29 & 36,3 \\
& & Perempuan & 51 & 63,7 \\
2. & & $\mathbf{8 0}$ & $\mathbf{1 0 0}$ \\
& Jumlah & $18-28$ & 67 & 83,75 \\
& Usia & $29-39$ & 11 & 13,75 \\
& & $40-50$ & 2 & 2,5 \\
3. & & $\mathbf{8 0}$ & $\mathbf{1 0 0}$ \\
& Jumlah & 52 & 65 \\
& & 28 & 35 \\
4. & Jumlidikan terakhir & Sarjana & $\mathbf{8 0}$ & $\mathbf{1 0 0}$ \\
& Pekerjaan & & 75 & 93,75 \\
& & Pelajar & 0 & 0 \\
& Jumlah & PNS/ANS & 5 & 6,25 \\
& & & $\mathbf{8 0}$ & $\mathbf{1 0 0}$ \\
\hline
\end{tabular}

Sumber : Data primer diolah, 2018

Menurut data yang tersaji pada Tabel 2 tentang karakteristik responden, berdasarkan kriteria jenis kelamin, jumlah responden laki - laki berjumlah 29 orang dengan presentase 36,3 persen dan responden perempuan berjumlah 51 orang dengan presentase 63,7 persen.

Dalam karakteristik responden berdasarkan kriteria usia, responden dengan rentang usia 18 - 28 tahun mendominasi dengan presentase 83,75 persen, sedangkan presentase terendah dimiliki oleh responden dengan rentang usia 40 50 tahun dengan presentase 2,5 persen.

Kriteria pendidikan terakhir responden didominasi oleh responden dengan pendidikan akhir tingkat SMA/SMK sejumlah 52 responden dengan presentase sebesar 65 persen diikuti oleh responden dengan pendidikan terakhir perguruan tinggi sebesar 35 persen dengan jumlah 28 responden. Dalam kriteria pekerjaan, pelajar mendominasi yaitu sejumlah 75 responden dengan presentase sebesar 93,75 persen.

Pengujian validitas dilakukan dengan menggunakan korelasi Pearson Product Moment dengan koefisien korelasi $\geq 0,3$ (cut off $\geq 0,3$ ). dalam penelitian ini yang mana akan di paparkan pada Tabel 4.2 sebagai berikut. 
Tabel 3.

Hasil Uji Validitas Instrumen Penelitian

\begin{tabular}{|c|c|c|c|c|c|c|}
\hline Variabel & & Indikator & $\begin{array}{c}\text { Correlation } \\
\text { Item }\end{array}$ & Keterangan & $\begin{array}{c}\text { Cronbach's } \\
\text { Alpha }\end{array}$ & Keterangan \\
\hline \multirow{5}{*}{$\begin{array}{l}\text { Persepsi } \\
\text { kualitas }\end{array}$} & $\mathrm{X}_{1.1}$ & Kualitas tinggi & 0,878 & Valid & \multirow{5}{*}{0,818} & \multirow{5}{*}{ Reliabel } \\
\hline & $\mathrm{X}_{1.2}$ & $\begin{array}{l}\text { Kualitas yang } \\
\text { konsisten }\end{array}$ & 0,880 & Valid & & \\
\hline & $\mathrm{X}_{1.3}$ & $\begin{array}{l}\text { Konsisten } \\
\text { Kenyamanan } \\
\text { Produk }\end{array}$ & 0,804 & Valid & & \\
\hline & $\mathrm{X}_{1.4}$ & Produk diandalkan & 0,849 & Valid & & \\
\hline & $\mathrm{X}_{1.5}$ & Tidak cepat rusak & 0,881 & Valid & & \\
\hline \multirow{3}{*}{$\begin{array}{l}\text { Citra } \\
\text { merek }\end{array}$} & $\mathrm{X}_{2.1}$ & $\begin{array}{l}\text { Keunggulan } \\
\text { asosiasi merek }\end{array}$ & 0,896 & Valid & \multirow{3}{*}{0,863} & \multirow{3}{*}{ Reliabel } \\
\hline & $\mathrm{X}_{2.2}$ & $\begin{array}{l}\text { Kekuatan asosiasi } \\
\text { mrek }\end{array}$ & 0,917 & Valid & & \\
\hline & $\mathrm{X}_{2.3}$ & $\begin{array}{l}\text { Keunikan asosiasi } \\
\text { merek }\end{array}$ & 0,892 & Valid & & \\
\hline \multirow{4}{*}{$\begin{array}{l}\text { Loyalitas } \\
\text { merek }\end{array}$} & $\mathrm{Y}_{1.1}$ & $\begin{array}{l}\text { Kesetiaan } \\
\text { Konsumen }\end{array}$ & 0,941 & Valid & \multirow{4}{*}{0,848} & \multirow{4}{*}{ Reliabel } \\
\hline & $\mathrm{Y}_{1.2}$ & Prioritas Pilihan & 0,846 & Valid & & \\
\hline & $\mathrm{Y}_{1.3}$ & $\begin{array}{l}\text { Tidak akan } \\
\text { berpindah ke merek } \\
\text { lain }\end{array}$ & 0,940 & Valid & & \\
\hline & $\mathrm{Y}_{1.4}$ & $\begin{array}{l}\text { Merekomendasikan } \\
\text { produk kepada } \\
\text { orang lain }\end{array}$ & 0,910 & Valid & & \\
\hline \multirow{4}{*}{$\begin{array}{l}\text { Ekuitas } \\
\text { merek }\end{array}$} & $\mathrm{Y}_{2.1}$ & Diferensiasi & 0,849 & Valid & \multirow{4}{*}{0,832} & \multirow{4}{*}{ Reliabel } \\
\hline & $\mathrm{Y}_{2.2}$ & Relevansi & 0,924 & Valid & & \\
\hline & $\mathrm{Y}_{2.3}$ & Harga Diri & 0,850 & Valid & & \\
\hline & $\mathrm{Y}_{2.4}$ & Pengetahuan & 0,836 & Valid & & \\
\hline
\end{tabular}

Sumber : Data primer diolah, 2018

Tabel 3. menunjukkan bahwa seluruh instrumen dalam variabel pengaruh persepsi kualitas dan citra merek terhadap loyalitas merek dalam membangun ekuitas merek memiliki pearson correlation yang lebih besar dari angka 0,30 . Hal tersebut menunjukkan bahwa seluruh instrumen variabel dalam penelitian ini adalah valid sehingga dapat digunakan sebagai instrumen penelitian.

Berdasarkan hasil uji reliabilitas seluruh Cronbach's Alpha menunjukkan nilai lebih dari 0,6. Hal tersebut menunjukkan bahwa semua instrumen reliabel atau memiliki konsistensi atau kehandalan dalam mengukur variabel dalam penelitian ini, sehingga dapat digunakan untuk melakukan penelitian.

Untuk menganalisis model penelitian, digunakan metode Partial Least Square (PLS) dengan alat bantu program SmartPLS 3.0 M3. Terdapat dua evaluasi model mendasar dalam pengujian ini yaitu outer model dan inner model.

Outer model merupakan model pengukuran untuk menilai validitas dan realibilitas model. Uji validitas dilakukan untuk mengetahui kemampuan instrument penelitian mengukur apa yang seharusnya diukur Uji validitas terbagi menjadi dua yaitu validitas konvergen dan diskriminan.

Sedangkan uji realibilitas digunakan untuk mengukur konsistensi alat ukur dalam mengukur suatu konsep atau dapat juga digunakan untuk mengukur 
konsistensi responden dalam menjawab item pertanyaan dalam kuesioner atau instrument penelitian

Tabel 4.

Outer loadings

\begin{tabular}{cccc}
\hline Variabel & Indikator & Outer Loading & Keterangan \\
\hline \multirow{5}{*}{ Persepsi kualitas } & $\mathrm{X}_{1.1}$ & 0,837 & Valid \\
& $\mathrm{X}_{1.2}$ & 0,823 & Valid \\
& $\mathrm{X}_{1.3}$ & 0,814 & Valid \\
& $\mathrm{X}_{1.4}$ & 0,861 & Valid \\
& $\mathrm{X}_{1.5}$ & 0,805 & Valid \\
Citra merek & $\mathrm{X}_{2.1}$ & 0,888 & Valid \\
& $\mathrm{X}_{2.2}$ & 0,843 & Valid \\
& $\mathrm{X}_{2.3}$ & 0,889 & Valid \\
& $\mathrm{Y}_{1.1}$ & 0,925 & Valid \\
Loyalitas merek & $\mathrm{Y}_{1.2}$ & 0,929 & Valid \\
& $\mathrm{Y}_{1.3}$ & 0,921 & Valid \\
& $\mathrm{Y}_{1.4}$ & 0,880 & Valid \\
& $\mathrm{Y}_{2.1}$ & 0,819 & Valid \\
Ekuitas merek & $\mathrm{Y}_{2.2}$ & 0,788 & Valid \\
& $\mathrm{Y}_{2.3}$ & 0,802 & Valid \\
& $\mathrm{Y}_{2.4}$ & 0,828 & Valid \\
\hline
\end{tabular}

Sumber : Data primer diolah, 2018

Berdasarkan Tabel 4. menunjukkan bahwa seluruh nilai outer loading indikator memiliki nilai di atas 0,50. Dengan demikian, dapat disimpulkan bahwa pengukuran convergent validity telah memenuhi persyaratan convergent validity.

Metode lain untuk menilai discriminant validity adalah dengan membandingkan akar kuadrat dari average variance extracted untuk setiap variabel dengan korelasi antara variabel dengan variabel lainnya dalam model.

Model mempunyai discriminant validity yang cukup jika akar kuadrat AVE untuk setiap variabel lebih besar daripada korelasi antara variabel dan variabel lainnya dalam model.

Untuk memastikan bahwa tidak ada masalah terkait pengukuran, maka dilakukan uji reliabilitas variabel yang diukur dengan dua kriteria yaitu composite reliability dan cronbachs alpha dari blok indikator yang mengukur variabel. Variabel dinyatakan reliabel jika nilai composite reliability maupun cronbachs alpha diatas 0,60. (Abdillah \& Jogiyanto, 2015).

Selanjutnya, model pengaruh persepsi kualitas, citra merek dan loyalitas merek terhadap ekuitas merek memberikan nilai $R$-square sebesar 0,477 yang dapat diinterpretasikan bahwa variabilitas variabel ekuitas merek dapat dijelaskan oleh variabilitas variabel persepsi kualitas, citra merek dan loyalitas merek sebesar 47,7 persen, sedangkan sisanya sebesar 52,3 persen dijelaskan oleh variabel lain diluar yang diteliti. 
Tabel 5.

Validitas Diskriminan

\begin{tabular}{|c|c|c|c|c|c|c|}
\hline \multirow[b]{2}{*}{$\begin{array}{l}\text { Variabel } \\
\text { Penelitian }\end{array}$} & \multirow[b]{2}{*}{ AVE } & \multirow[b]{2}{*}{$\begin{array}{l}\text { Akar } \\
\text { AVE }\end{array}$} & \multicolumn{4}{|c|}{ Korelasi } \\
\hline & & & $\begin{array}{c}\text { Persepsi } \\
\text { kualitas } \\
\left(\mathrm{X}_{1}\right)\end{array}$ & $\begin{array}{c}\text { Citra } \\
\text { merek } \\
\left(\mathbf{X}_{2}\right)\end{array}$ & $\begin{array}{c}\text { Loyalitas } \\
\text { merek }\left(\mathbf{Y}_{1}\right)\end{array}$ & $\begin{array}{c}\text { Ekuitas } \\
\text { merek }\left(\mathbf{Y}_{2}\right)\end{array}$ \\
\hline $\begin{array}{c}\text { Persepsi } \\
\text { kualitas }\left(\mathrm{X}_{1}\right)\end{array}$ & 0,686 & 0,828 & 1,000 & & & \\
\hline $\begin{array}{l}\text { Citra merek } \\
\quad\left(\mathrm{X}_{2}\right)\end{array}$ & 0,764 & 0,874 & 0,731 & 1,000 & & \\
\hline $\begin{array}{l}\text { Loyalitas } \\
\text { merek }\left(\mathrm{Y}_{1}\right)\end{array}$ & 0,835 & 0,914 & 0,598 & 0,640 & 1,000 & \\
\hline $\begin{array}{c}\text { Ekuitas merek } \\
\left(\mathrm{Y}_{2}\right)\end{array}$ & 0,655 & 0,809 & 0,672 & 0,646 & 0,691 & 1,000 \\
\hline
\end{tabular}

Tabel 6.

Composite Realibility dan Cronbach's Alpha

\begin{tabular}{lcc}
\hline \multicolumn{1}{c}{ Variabel } & Composite Reliability & Cronbach's Alpha \\
\hline Persepsi kualitas $\left(\mathrm{X}_{1}\right)$ & 0,916 & 0,885 \\
Citra merek $\left(\mathrm{X}_{2}\right)$ & 0,906 & 0,847 \\
Loyalitas merek $\left(\mathrm{Y}_{1}\right)$ & 0,953 & 0,934 \\
Ekuitas merek $\left(\mathrm{Y}_{2}\right)$ & 0,884 & 0,825 \\
\hline
\end{tabular}

Sumber : Data primer diolah, 2018

Tabel 7.

R-square

\begin{tabular}{cc}
\hline Variabel & $\boldsymbol{R}$-square \\
\hline Loyalitas merek $\left(\mathrm{Y}_{1}\right)$ & 0,446 \\
Ekuitas merek $\left(\mathrm{Y}_{2}\right)$ & 0,477 \\
\hline
\end{tabular}

Sumber : Data primer diolah, 2018

Untuk mengukur seberapa baik nilai observasi dihasilkan oleh model dan juga estimasi parameternya, maka perlu menghitung $Q$-square. Nilai $Q$-square memiliki rentang nilai $0<\mathrm{Q}^{2}<1$, dimana semakin mendekati 1 berarti model semakin baik. Penelitian nilai Q-squares pada penelitian ini dilakukan sebagai berikut.

$$
\begin{aligned}
\mathrm{Q}^{2} & =1-\left(1-\left(\mathrm{R}_{1}^{2}\right)\right)\left(1-\left(\mathrm{R}_{2}^{2}\right)\right) \ldots \\
& =1-(1-0,446)(1-0,477) \\
& =1-(0,554)(0,523) \\
& =1-0,289 \\
& =0,711
\end{aligned}
$$

Hasil perhitungan tersebut didapat nilai $Q$-square adalah sebesar 0,711 , sehingga dapat disimpulkan bahwa model memiliki predictive relevance yang baik. Dengan demikian, dapat dijelaskan bahwa 71,1 persen variasi pada ekuitas 
merek dipengaruhi oleh persepsi kualitas, citra merek dan loyalitas merek, sedangkan sisanya sebesar 28,9 persen dipengaruhi oleh variabel lain.

Berdasarkan kedua hasil perhitungan diatas $\mathrm{R}^{2}$ dan $\mathrm{Q}^{2}$ dengan kriteria model yang kuat dan baik, maka dapat dilanjutkan dengan analisis pengujian hipotesis.

Model struktural disebut sebagai model reflektif dimana covariance pengukuran indikator dipengaruhi oleh konstruk laten atau mencerminkan variasi dari konstruk unidimensional yang digambarkan dengan bentuk elips dengan beberapa anak panah dari konstruk ke indikator. Model ini menghipotesiskan bahwa perubahan pada konstruk laten akan mempengaruhi perubahan pada indikator.

Pengujian parameter yang diestimasi memberikan informasi yang sangat berguna mengenai hubungan antara variabel-variabel penelitian. Dasar yang digunakan dalam menguji hipotesis adalah nilai yang terdapat pada output path coefficients.

Pada penelitian ini telah ditentukan sebelumnya nilai T-tabel dengan signifikansi pa $\alpha=0.05$ dengan nilai T-Statistik lebih besar dari t-hitung $(1,99)$. Tiga koefisien jalur pada Tabel 4.15 memiliki nilai T-Statistik di atas 1.99 sehingga dinyatakan memiliki pengaruh yang signifikan.

\section{Tabel 8.}

Path Coefficient (Mean, STDEV, T-Values, P-Values)

\begin{tabular}{lcccccc}
\hline & & $\begin{array}{c}\text { Sampel } \\
\text { Asli (O) }\end{array}$ & $\begin{array}{c}\text { Sampel } \\
\text { Mean (M) }\end{array}$ & $\begin{array}{c}\text { Standar } \\
\text { Deviasi } \\
\text { (STDEV) }\end{array}$ & $\begin{array}{c}\text { T Statistik } \\
(\mid \mathbf{O} / \text { STERR|) }\end{array}$ & $\begin{array}{c}\text { P. } \\
\text { Values }\end{array}$ \\
\hline $\mathrm{PK}\left(\mathrm{X}_{1}\right)$ & $->\mathrm{LM}\left(\mathrm{Y}_{1}\right)$ & 0,280 & 0,274 & 0,136 & 2,063 & 0,040 \\
$\mathrm{CM}\left(\mathrm{X}_{2}\right)$ & $->\mathrm{LM}$ & 0,435 & 0,440 & 0,140 & 3,106 & 0,002 \\
$(\mathrm{Y}$ & & & & & & \\
$\mathrm{LM}\left(\mathrm{Y}_{1}\right)$ & $->\mathrm{EM}$ & 0,691 & 0,694 & 0,057 & 12,126 & 0,000 \\
$\left(\mathrm{Y}_{2}\right)$ & & & & & & \\
\hline
\end{tabular}

Sumber : Data primer diolah, 2018

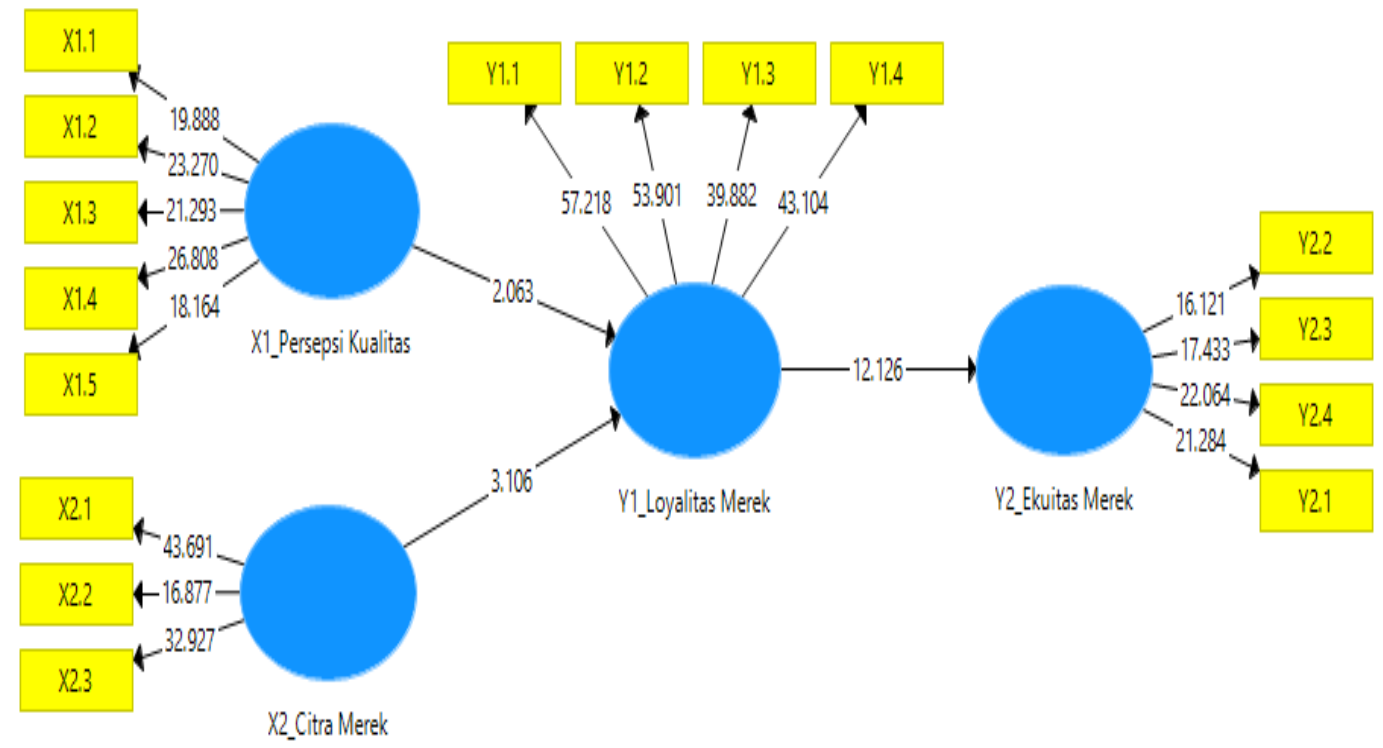

Gambar 1. Diagram Jalur Model Analisis 
$\mathrm{F}$ - square atau effect size merupakan ukuran mengenai besarnya efek suatu variabel pada variabel lain, besarnya perbedaan maupun hubungan, yang bebas dari pengaruh besarnya sampel (Olejnik \& Algina, 2000).

Tabel 9.

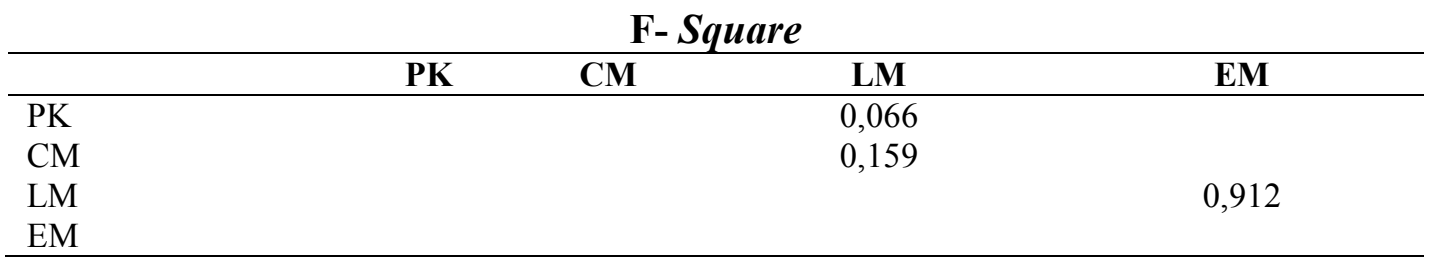

Sumber : Data primer diolah, 2018

Variabel-variabel yang terkait biasanya berupa variabel respon, atau disebut juga variabel independen dan variabel hasil (outcome variable), atau sering disebut variabel dependen. Nilai effect size berada diantara $0-1$, beberapa penelitian kerap menghasilkan effect size lebih dari satu.

Berdasarkan Tabel 9. diatas, hubungan antar variabel persepsi kualitas dengan loyalitas merek adalah siginfikan namun memiliki efek yang lemah karena memiliki effect size sebsar 0.066 yang berada dalam rentang $0-0.20$ dengan kategori lemah.

Begitu juga dengan hubungan antar variabel citra merek terhadap loyalitas merek adalah signifikan namun memiliki efek yang lemah karena memiliki effect size sebsar 0.159 yang berada dalam rentang lemah.

Selanjutnya hubungan antar variabel loyalitas merek terhadap ekuitas merek memiliki hubungan yang signifikan dan efek yang kuat karena memiliki effect size sebesar 0,912 dan masuk dalam kategori kuat. Persepsi kualitas terbukti berpengaruh positif dan signifikan terhadap loyalitas merek.

Hasil ini ditunjukkan oleh koefisien jalur yang bernilai positif sebesar 0,280 dengan t-statistic sebesar 2,063 (t-statistic $>1,99$ ) dan nilai $p$ value $0,040<0,050$, dengan demikian, maka hipotesis $1\left(\mathrm{H}_{1}\right)$ dapat dibuktikan.

Hasil rangkuman penilaian responden menunjukkan bahwa penilaian responden terhadap persepsi kualitas berada dalam kategori baik. Responden merasa Reebok memiliki kualitas yang tinggi, kualitas yang konsisten, dan kenyamanan yang baik saat digunakan. Responden merasa Reebok cukup dapat diandalkan. Responden juga merasa Reebok tidak cepat rusak.

Dalam kuesioner hasil terendah terdapat dalam "Reebok dapat diandalkan". Hal ini dapat terjadi karena didalam latar belakang terdapat pendapat konsumen dari Reebok yang menyatakan bahwa beberapa bagian dalam sepatu Reebok terlepas hanya dalam pemakaian beberapa bulan. Dengan terlepasnya beberapa bagian pada sepatu Reebok menyebabkan sepatu Reebok tidak dapat diandalkan dengan maksimal.

Hasil penelitian ini sesuai dengan rumusan hipotesis yang menyatakan bahwa persepsi kualitas berpengaruh positif dan signifikan terhadap loyalitas merek yang artinya semakin tinggi persepsi kualitas, maka loyalitas merek akan semakin meningkat. 
Hasil penelitian ini mendukung penelitian yang dilakukan oleh Vinh et al. (2017) mengenai destinasi wisata di Danang, penelitian oleh Nofriyanti (2017) mengenai provider telpon seluler, dan penelitian yang dilakukan oleh Eliasari \& Sukaatmadja (2017) mengenai merek air minum Kaori.

Citra merek terbukti berpengaruh positif dan signifikan terhadap loyalitas merek. Hasil ini ditunjukkan oleh koefisien jalur yang bernilai positif sebesar 0,435 dengan t-statistic sebesar 3,106 (t-statistic $>1,99$ ), dan nilai $p$ value $0,002<$ 0,050 , dengan demikian, maka hipotesis $2\left(\mathrm{H}_{2}\right)$ dapat dibuktikan. Hasil yang diperoleh dapat dimaknai bahwa semakin baik citra merek, maka loyalitas merek akan semakin meningkat.

Hasil rangkuman penilaian responden menunjukkan bahwa penilaian responden terhadap citra merek berada dalam kategori cukup. Responden merasa cukup dengan keunggulan Reebok dalam persaingan. Responden merasa Reebok mudah untuk diingat berada dalam kategori tinggi. Responden juga merasa Reebok memiliki perbedaan yang cukup dikenal oleh responden.

Hasil penelitian ini sesuai dengan rumusan hipotesis yang menyatakan bahwa citra merek berpengaruh positif dan signifikan terhadap loyalitas merek yang artinya semakin tinggi citra merek, maka loyalitas merek akan semakin meningkat.

Dalam kuesioner hasil terendah terdapat dalam "Reebok unggul dalam persaingan". Hal ini dapat terjadi karena persaingan dengan merek lainnya dalam kategori sepatu olahraga. Desain-desain terbaru dalam sepatu olahraga dapat menjadi pertimbangan konsumen dalam memilih sepatu olahraga.

Hasil penelitian ini mendukung penelitian yang dilakukan oleh Kurniawan (2017) mengenai rumah makan cepat saji, dan Nofriyanti (2017) mengenai provider telpon seluler, serta penelitian oleh Fatema et al. (2013) mengenai Islami Bank Bangladesh.

Loyalitas merek terbukti berpengaruh positif dan signifikan terhadap ekuitas merek. Hasil ini ditunjukkan oleh koefisien jalur yang bernilai positif sebesar 0,691 dengan $\mathrm{t}$-statistic sebesar 12,126 (t-statistic $>1,99$ ), dan nilai $\mathrm{p}$ value 0,000 $<0,050$, dengan demikian, maka hipotesis $3\left(\mathrm{H}_{3}\right)$ dapat dibuktikan. Hasil yang diperoleh dapat dimaknai bahwa semakin tinggi tingkat loyalitas merek, maka ekuitas merek akan semakin meningkat.

Hasil rangkuman penilaian responden menunjukkan bahwa penilaian responden terhadap loyalitas merek berada dalam kategori cukup. Responden merasa cukup dengan selalu memilih Reebok dan Reebok sebagai pilihan pertama. Responden tidak akan berpindak ke merek lain berada dalam kategori tidak baik. Responden juga merasa cukup untuk merekomendasikan Reebok kepada orang lain.

Hasil penelitian ini sesuai dengan rumusan hipotesis yang menyatakan bahwa loyalitas merek berpengaruh positif dan signifikan terhadap ekuitas merek yang artinya semakin tinggi loyalitas merek, maka ekuitas merek akan semakin meningkat.

Dalam kuesioner hasil terendah terdapat dalam "Saya akan selalu memilih untuk membeli Reebok". Hal ini dapat terjadi karena terdapat banyaknya merek 
lainnya dalam sepatu olahraga. Kurangnya hubungan yang baik dengan pelanggan akan menyebabkan pelanggan mudah untuk berpidah ke merek lainnya.

Hasil penelitian ini mendukung penelitian yang dilakukan oleh Torres et al. (2015) mengenai minuman beralkohol, dan Sasmita \& Norazah (2014) mengenai produk dan merek di media sosial, serta penelitiano oleh Kashif et al. (2015) mengenai destinasi wisata.

Berdasarkan hasil penelitian yang dilakukan menunjukkan bahwa penelitian ini telah mampu mengkonfirmasi sekaligus memperkuat adanya pengaruh persepsi kualitas dan citra merek terhadap loyalitas merek untuk membangun ekuitas merek. Berikut beberapa implikasi dari hasil penelitian yang diperoleh.

Pertama, berdasarkan hasil penelitian mengenai pengaruh persepsi kualitas terhadap loyalitas merek berhubungan positif yaitu dengan menciptakan kualitas yang tinggi; kualitas yang konsisten; kenyamanan saat digunakan; dapat diandalkan; dan tidak cepat rusak.

Kedua, berdasarkan hasil penelitian mengenai pengaruh citra merek berpengaruh signifikan terhadap loyalitas merek yaitu dengan menjaga keunggulan dalam persaingan; mudah untuk diingat; dan memiliki perbedaan yang mudah untuk diingat.

Terakhir, berdasarkan hasil penelitian mengenai pengaruh loyalitas merek terhadap ekuitas merek yaitu dengan menjaga kesetiaan konsumen untuk selalu membeli; menjadi pilihan pertama; konsumen tidak berpindah ke merek lain; dan konsumen merekomendasikan produk kepada orang lain.

Hasil penelitian ini menunjukkan persepsi kualitas dan citra merek memiliki peran dalam loyalitas merek kepada meningkatnya ekuitas merek. Berdasarkan hal tersebut, penting bagi pihak Reebok untuk dapat memberikan kepuasan bagi pelanggannya, memenuhi apa yang pelanggan inginkan, menjadikan sepatu olahraga Reebok sebagai hal bagi pelanggan dalam berolahraga.

Berdasarkan penelitian yang telah dilakukan, adapun beberapa keterbatasan dalam penelitian ini. Penelitian ini meneliti pengaruh persepsi kualitas dan citra merek terhadap loyalitas merek untuk membangun ekuitas merek sepatu olahraga Reebok sedangkan terdapat variabel lain seperti kesadaran merek dan asosiasi merek yang dapat mempengaruhi ekuitas merek, sehingga penelitian selanjutnya dapat dilakukan.

Penelitian ini tidak dapat digeneralisasikan untuk seluruh Indonesia karena hanya dilakukan di Kota Jakarta dan Kota Denpasar. Selain itu lingkungan yang dinamis juga dapat menyebabkan perubahan sehingga penelitian ini perlu dilakukan kembali.

\section{SIMPULAN}

Berikut adalah kesimpulan yang dapat diambil berdasarkan pembahasan sebelumnya. Persepsi kualitas berpengaruh secara positif dan signifikan terhadap loyalitas merek, dan persepsi kualitas pelanggan terhadap Reebok akan mempengaruhi loyalitasnya terhadap Reebok. Dengan kata lain semakin baik persepsi kualitas yang dimiliki pelanggan maka loyalitas pelanggan terhadap merek Reebok akan semakin meningkat. Citra merek berpengaruh positif dan signifikan terhadap loyalitas merek, sehingga citra merek merupakan faktor yang 
penting dalam loyalitas merek Reebok. Dapat dikatakan bahwa jika pelanggan merasa citra merek Reebok baik, maka pelanggan akan semakin loyal terhadap Reebok. Selain itu, loyalitas merek berpengaruh secara positif dan signifikan terhadap ekuitas merek. Hal ini berarti semakin tinggi loyalitas pelanggan terhadap merek Reebok akan meningkatkan ekuitas merek Reebok juga. Berdasarkan hasil penelitian tersebut, berikut adalah saran yang diharapkan dapat membantu pihak Reebok dan peneliti selanjutnya yaitu: Reebok dapat meningkatkan persepsi kualitas dengan meningkatkan keandalan sepatunya. Hal ini dapat dilakukan dengan cara meningkatkan fitur-fitur yang terdapat dalam sepatu Reebok sehingga pelanggan dapat merasakan sepatu Reebok dapat lebih diandalkan dalam berolahraga. Hal yang dapat dilakukan Reebok adalah dengan meningkatkan daya tahan sepatu terhadap kondisi lingkungan.

Reebok perlu meningkatkan citra mereknya dengan memperkenalkan desain sepatu yang unik dan berkualitas sehingga dapat lebih diminati oleh pelanggan. Persepsi kualitas memiliki pengaruh yang lebih besar dibandingkan citra merek dalam meningkatkan loyalitas merek. Pihak Reebok sebaiknya tetap menjaga persepsi kualitas agar pelanggan terus merasa puas tiap kali menggunakan Reebok dalam berolahraga. Namun Reebok juga harus tetep menjaga citra merek karena dapat mempengaruhi loyalitas merek. Reebok dapat lebih memprioritaskan persepsi kualitas dibandingkan citra mereknya untuk menjaga loyalitas pelanggan sehingga ekuitas merek Reebok dapat ditingkatkan. Reebok sebaiknya menjalin hubungan yang baik secara berkelanjutan dengan konsumen agar konsumennya tidak berpindah ke merek lain. Reebok dapat melakukannya dengan cara membuat aplikasi loyalty program, membership, dan reward untuk memberikan kenyamanan bagi pelanggannya.

Ekuitas merek Reebok dapat ditingkatkan dengan menambah pengetahuan konsumen terhadap produk-produk sepatu Reebok. Pihak Reebok dapat membuat iklan untuk setiap produk barunya dengan mengajak brand ambassador yang terkenal diantara penggunanya sehingga pelanggan akan lebih tertarik untuk mengenal produk baru Reebok. Untuk peneliti selanjutnya diharapkan dapat melakukan penelitian pada lokasi penelitian yang berbeda dan menambahkan variabel-variabel lainnya seperti kesadaran merek dan asosiasi merek agar dapat memberikan masukan yang berbeda dalam membangun ekuitas merek.

\section{REFERENSI}

Aaker, D. (2013). Manajemen Pemasaran Strategis (Strategic Marketing Management) (Delapan). Jakarta: Salemba Empat.

Abdillah, W., \& Jogiyanto. (2015). Partial Least Square (PLS) - Alternatif Structural Equation Modeling (SEM) Dalam Penelitian Bisnis. Yogyakarta: Penerbit Andi.

Alam, W., Saeed, T., \& Malik, Z. (2016). Role of Brand Image on Brand Equity: A Comparative Study of Public and Private Sector Higher Education Institutions of Khyber Pakhtunkhwa. City University Research Journal, 6(1), 
$48-60$.

Chung, Y. ., Lee, J., \& Heath, L. . (2013). Public Relations Aspects Of Brand Attitudes And Customer Activity. Public Relations Review, 39(5), 432-439.

Eliasari, P. R. ., \& Sukaatmadja, I. P. . (2017). Pengaruh Brand Awareness terhadap Purchase Intention dimediasi oleh Perceived Quality dan Brand Loyalty. E-Jurnal Manajemen Unud, 6(12), 6620-6650.

Emari, H., Jafari, A., \& Mogaddam, M. (2012). The Mediatory Impact Of Brand Loyalty And Brand Image On Brand Equity. African Journal of Business Management, 6(17), 5692-5701.

Fatema, M., Azad, A. K., \& Masum, A. K. (2013). Impact of Brand Image and Brand Loyalty in Measuring Brand Equity of Islami Bank Bangladesh Ltd. Asian Business Review, 2(2), 42-46.

Hamdani, T. (2018). Naik 8\%, Ini Perkiraan UMP 2019 Di 34 Provinsi. Retrieved from https://finance.detik.com/berita-ekonomi-bisnis/d-4260868/naik-8-iniperkiraan-ump-2019-di-34-provinsi (diakses Januari 2019)

Hasanah, E. . (2009). Studi Mengenai Brand Loyalty Dalam Meningkatkan Brand Equity. Universitas Diponegoro.

Huang, R., \& Sarigollu, E. (2011). How Brand Awareness Relates To Market Outcome, Brand Equity, And The Marketing Mix. Journal of Business Research, 65(1), 92-99.

Indonesia Top Brand. (2018). About Top Brand. Retrieved from http://www.topbrand-award.com/about-top-brand (diakses Mei 2018)

Indriani, L. (2015). Pengaruh Pendapatan, Gaya Hidup, dan Jenis Kelamin Terhadap Tingkat Konsumsi Mahasiswa Fakultas Ekonomi Universitas Negeri Yogyakarta. Universitas Negeri Yogyakarta.

Janghyeon, N. K., Yuksel, E., \& Georgina, W. (2011). Brand Equity And Brand Loyalty And Consumer Satisfaction. Journal Annals of Tourism Research, 38(3), 1009-1030.

Jing, Z., Pitsaphol, C., \& Shabbir, R. (2014). The Influence of Brand Awareness, Brand Image and Perceived Quality on Brand Loyalty: A Case Study of Oppo Brand In Thailand. Interdisciplinary Journal of Contemporary Research in Business, 5(12), 10-21.

Kashif, M., Melatusamsi, S. ., \& Sarufuddin, S. (2015). Brand Equity Of Lahore Fort As A Tourism Destination Brand. Revista De Administração De Empresas, 55(4), 432-443.

Keller, K. L. (2003). Strategic Brand Management: Building, Measuring, And Managing Brand Equity (2nd ed). NJ: Prentice Hall. 
Keller, K. L., \& Lehmann. (2006). Brands and Branding: Research Findings and Future Priorities. Marketing Science, 25(6), 740-759.

Kocoglu, C., Tengilimoglu, D., Ekiyor, A., \& Guzel, A. (2015). The Effects of Brand Loyalty on the Consumer Buying Behaviors: The Example of Perfume in the Province of Ankara. International Journal of Humanities and Management Sciences, 3(5), 318-323.

Kotler, P. (2015). Manajemen Pemasaran Jilid 2 (11th ed.). Jakarta: Indeks.

Kotler, P., \& Amstrong. (2014). Principles of Marketing: Global Edition (15th Editi). England: Pearson.

Kotler, P., \& Keller, K. . (2012). Manajemen Pemasaran Jilid I (Edisi 12). Jakarta: Erlangga.

Kurniawan, H. . (2017). Pengaruh Perceived Quality Terhadap Brand Loyalty Melalui Mediasi Brand Image Dan Brand Trust. Jurnal Bisnis Dan Manajemen, 4(2), 228-239.

Kuscu, A., \& Ozcam. (2014). Analyzing Factors Affecting Repurchase Intention During Gezi Park Brand Protests. European Journal of Business and Management, 6(38), 177-188.

Nofriyanti, A. . (2017). Pengaruh Brand Trust, Brand Image, Perceived Quality, Brand Loyalty Terhadap Brand Equity Pengguna Telkomsel. EKOBISEkonomi Bisnis, 22(2), 130-142.

Olejnik, S., \& Algina, J. (2000). Measures of Effect Size for Comparative Studies: Applications, Interpretations, and Limitations. Contemporary Educational Psychology, 25(3), 241-286.

Putra, A. S. S., \& Suryani, A. (2015). Peran Green Trust dalam Memediasi Green Perceived Value terhadap Green Purchase Behaviour Pada Produk Organik. E-Jurnal Manajemen Unud, 4(1), 3015-3036.

Rafdi, M. . (2015). The Relationship Of Team Identification And Customer Satisfaction To Brand Loyalty Case Study: European Soccer Club's Nike Jersey Purchasing By Binus University Student. Universitas Bina Nusantara.

Said, H. (2014). Mobile Phone Brand Loyalty And Repurchase Intention. European Journal of Business and Management, 6(26), 69-72.

Sasmita, J., \& Norazah, M. S. (2014). Young Consumers' Insights On Brand Equity Effects Of Brand Association, Brand Loyalty, Brand Awareness, And Brand Image. International Journal of Retail \& Distribution Management, 43(3), 276-292.

Setyawan, B. (2010). Pengaruh Perceived Quality, Perceived Sacrifice, Perceived Value, Satisfaction Pada Behavioural Intentions. E-Jurnal Manajemen UNS, 1(32), 23-31. 
Sibagariang, S. C., \& Nursanti, T. D. (2010). Pengaruh Brand Image dan Brand trust Terhadap Brand Loyalty Pada PT Bank Sinarmas. The Winners, 11(2), $118-129$.

Torres, P. ., Mário, G. ., \& João, V. . (2015). Determining The Causal Relationships That Affect Consumer-Based Brand Equity The Mediating Effect Of Brand Loyalty. Marketing Intelligence \& Planning, 33(6), 944956.

Vinh, T. ., Nga, V. T. ., \& Nguyen, P. (2017). The Causal Relationships Between Components of Customer-Based Brand Equity for Danang City as a Tourism Destination. Asian Economic and Financial Review, 7(4), 358-367.

Zeithaml, V., Bitner, M. J., \& Gremler, D. (2013). Sevice Marketing Title (Sixth Edit). New York: Mc Graw-Hill.

Zhang, Y. (2015). The Impact of Brand Image on Consumer Behaviour:A Literature Review. Journal Business and Management, 3(1), 58-62. 